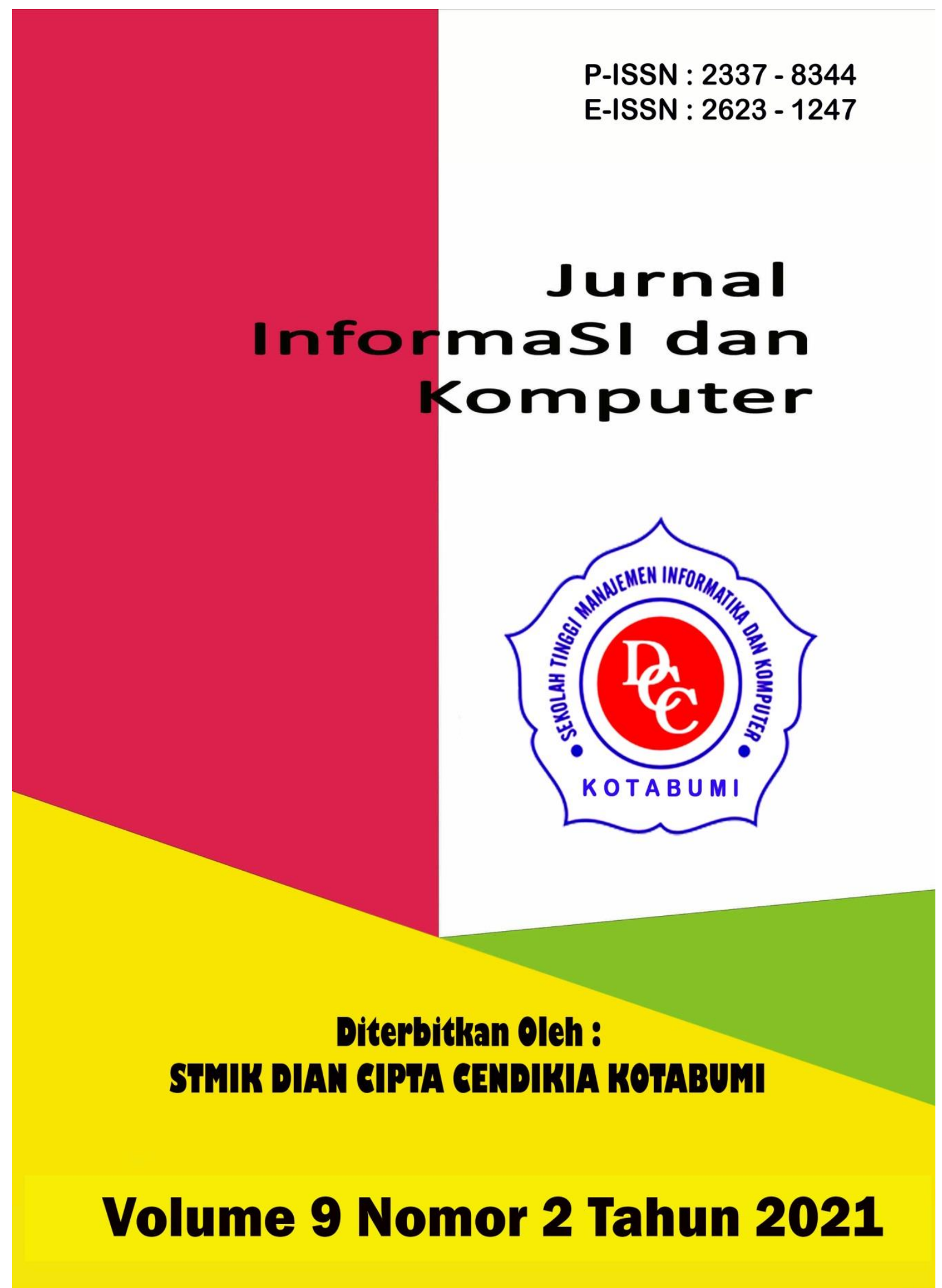




\section{Penerbit}

\section{Lembaga Penelitian STMIK Dian Cipta Cendikia Kotabumi}

Hak atas naskahh/tulisan tetap berada pada penulis, isi diluar tangung jawab penerbit dan Dewan Penyunting 


\section{PENGANTAR REDAKSI}

Puji syukur dipanjatkan kehadirat Tuhan Yang Maha Esa, atas karunia dan limpahan rahmatNYA jualah Jurnal Informasi dan komputer (JIK) STMIK Dian Cipta Cendikia Kotabumi ini dapat terwujud.Jurnal Informasi dan Komputer (JIK) yang terbit dua (2) kali dalam setahun ini merupakan suatu wadah untuk penyebar luasan hasil-hasil penelitian, studi pustaka, karya ilmiah yang berkaitan dengan Informasi dan Komputer khususnya bagi dosen-dosen STMIK Dian Cipta Cendikia Kotabumi serta umumnya para cendikiawan, praktisi, peneliti ilmu Informatika dan Komputer.

Harapan, dengan diterbitkannya Jurnal Informasi dan Komputer (JIK) ini sebagai salah satu bentuk sumbangan pemikiran dalam pengembangan ilmu informatika dan komputer yang berkaitan dengan kajian-kajian di bidang tekhnologi Informatik, Komunikasi Data dan Jaringan Komputer, perancangan dan Rekayasa Perangkat Lunak, serta ilmu-ilmu yang terkait dengan bidang Informasi dan Komputer lainnya.

Berkenaan dengan harapan tersebut, kepada para peneliti, dosen dan praktisi yang memiliki hasil-hasil penelitian, kajian pustaka, karya ilmiah dalam bidang tersebut diatas, dengan bangga redaksi Jurnal Informasi dan Komputer (JIK) menerima naskah ringkasan untuk dimuat pada jurnal Informasi dan Komputer (JIK) STMIK Dian Cipta Cendikia Kotabumi dengan berpedoman pada penulisan naskah jurnal sebagaimana dilampirkan pada halaman belakang (Bagian kulit dalam) buku jurnal ini.

Mutu dari suatu jurnal ilmiah tidak hanya ditentukan oleh para pengelolanya saja, tetapi para penulis dan pembaca jualah yang mempunyai peranan besar dalam meningkatkan mutu jurnal Informatika dan Komputer ini. Merujuk pada realita ini kamu sangat mengharapkan peran aktif dari peneliti untuk bersama-sama menjaga dan memelihara keberlangsungan dari jurnal Informasi dan Komputer STMIK Dian Cipta Cendikia Kotabumi ini. Yang juga tidak kalah pentingnya dari partisipasi tersebut diatas, adalah saran dan kritik yang membangun dari pembaca yang budiman agar kiranya dapat disampaikan langsung kepada redaksi JIK. Saran dan kritik yang membangun akan dijadikan masukan dan pertimbangan yang sangat berarti guna peningkatan mutu dan kualitas Jurnal Informasi dan Komputer STMIK Dian Cipta Cendikia Kotabumi.

Tak lupa diucapkan terima kasih yang tak terhingga atas perhatian dan kerjasama dari semua pihak yang tak dapat disebutkan satu persatu hingga dapat diterbitkan nya Jurnal Informasi dan Komputer (JIK) STMIK Dian Cipta Cendikia Kotabumi. Semoga apa yang telah diperbuat untuk kebaikan akan menjadi amal ibadah, amin.

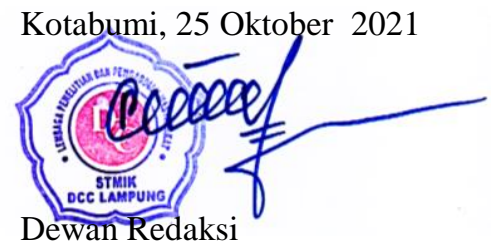




\section{JURNAL INFORMASI DAN KOMPUTER}

Volume 9 Nomor 2 Oktober 2021

Jurnal Informasi dan Komputer merupakan Sarana informasi ilmu pengetahuan, Tekhnologi dan Komunikasi yang berupa hasil penelitian, tulisan ilmiah, Ataupun studi pustaka. Jurnal ini terbit dua kali setahun pada bulan April dan Oktober. Berisi hasil penelitian ilmiah di bidang informatika yang bertujuan untuk menghubungkan adanya kesenjangan antar kemajuan teknologi dan hasil penelitian. Jurnal ini di terbitkan pertama kali pada tahun 2013.

Penanggung Jawab:

Ketua STMIK Dian Cipta Cendikia Kotabumi

\section{Pembina:}

Ketua STMIK Dian Cipta Cendikia Kotabumi Ketua Lembaga Penelitian STMIK Dian Cipta Cendikia Kotabumi

\section{Pimpinan Redaksi}

Dwi Marisa Efendi,.S.Kom.,M.Ti

\section{Redaksi pelaksana}

Rustam,.S.Kom,.M.Ti (STMIK Dian Cipta Cendikia Kotabumi)

Nurmayanti M.Kom (STMIK Dian Cipta Cendikia Kotabumi)

Sukatmi,.S.Kom., M.Kom (AMIK DCC Bandar Lampung)

Sampurna Dadi Riskiono,M.Kom (Universitas Teknokrat Indonesia)

Ifo Wahyu Pratama,S.Kom.,M.Ti(AMIK MASTER Lampung)

\section{Mitra Bestari}

Dr. RZ. ABDUL AZIZ, ST., MT (Institut Informatika dan Bisnis Darmajaya)

Dr. Dadang Sudrajat, S.Si, M.Kom (STMIK IKMI Cirebon)

Dr. Septafiansyah Dwi Putra, S.T., M.T (Politeknik Negeri Lampung)

Dr. Evi Grativiani, S.E., M.S.I (Universitas Sebelas Maret)

Rohmat Indra Borman ( Universitas Teknokrat Indonesia )

Ferry Wongso, S.KOm., M.Kom ( STMIK Darma Pala Riau)

Ferly Ardhy, S.Kom., M.Ti ( Universitas Aisyah Pringsewu )

Firmansyah, S.E., M.Si (STMIK Darma Pala Riau)
Amarudin (Universitas Teknokrat Indonesia)

Didi Susianto, S.T., M.Kom (AMIK Dian Cipta Cendika Bandar Lampung)

Alhibarsyah, St., M.Kom (STMIK Tunas

Bangsa Bandar Lampung)

Kemal Farouq Mauladi, S.Kom .M.Kom (Universitas Islam Lamongan)

Rima Mawarni, M.Kom ( STMIK Dian Cipta Cendikia Kotabumi)

Wira Jaya Hartono, S.Pd., M.Pd ( STMIK Darma Pala Riau)

Penerbit : STMIK Dian Cipta Cendikia Kotabumi Bekerja Sama Dengan LPPM STMIK Dian Cipta Cendikia Kotabumi.

\section{Alamat Redaksi/Penerbit:}

Jl. Negara No. 3 Candimas Kotabumi Lampung Utara

No Telpon/Fax 072423003

Email : 1ppm-stmik@dcc.ac.id 


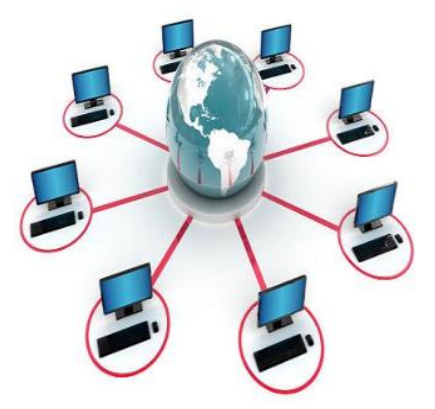

\section{JURNAL INFORMASI DAN KOMPUTER VOL. 9 NO. 2 THN. 2021}

\section{DAFTAR ISI}

Halaman

Sistem Informasi Akuntansi Persedian Barang Berbasis Web Pada Lembaga

Permasyarakatan Kelas II A Banceuy Bandung : "Kelompok Tani Desa Banjar Kertarahayu"

Teuku Rian Hardiyansyah, Fatia Salsa Azzahra

(Politeknik Piksi Ganesha Bandung ${ }^{1,2}$ ).....

Penerapan Finite State Automata Pada Vending Machine Penjual Obat Non Resep

Dokter Dan Keperluan Medis

Eko Supriyanto $^{1}$, Angga Ardiansyah ${ }^{2}$, Frieyadie $^{3}$, Sri Rahayu ${ }^{4}$, Windu Gata ${ }^{5}$

(Universitas Nusa Mandiri ${ }^{12}$ ) 08-14

Sistem Pendukung Keputusan Untuk Menentukan Kelayakan Pengajuan Sertifikasi Guru Dengan Metode Simple Additive Weighting (Studi Kasus : Ma Al Muhajirin Janti Jogoroto Jombang)

Budiman, umam baharudin, winarti

(Universitas Darul 'Ulum Jombang)

Perancangan Infrastruktur Domain Name Server Lokal Menggunakan Ubuntu Server 16.04

Pada PT. Xyz

Zaenal Mutaqin Subekti, Hendra Setiawan, Satria, Widia Murni Wijaya,

Aliy Hafiz, Warsudi

(STMIK Bani Saleh, Universitas Negeri Yogyakarta, AMIK Dian Cipta Cendikia,

STMIK MIC CIkarang)

Perancangan Sistem Informasi Idea Proposal (Ip) Berbasis Web Pada Pt. Paxel Algorita Unggul

Julian Murhan Sahputra, Indah Purnamasari

(Universitas Nusa Mandiri ${ }^{12}$ )

Sistem Pendukung Keputusan Untuk Menentukan Ekstrakurikuler Atletik

Berdasarkan Bakat Siswa Menggunakan Metode Profile Matching

Agnes Basuki, Petrus Sokibi, Tiara Eka Putri

(Universitas Catur Insan Cendekia)

Penerapan Algoritma K-Means Untuk Pengelompokan Usia Calon Penerima Vaksin

Di Kab. Ngawi

Irna Yuniarfi, Saifulloh

(Universitas PGRI Madiun $^{12}$ )

System Penilaian Seleksi Calon Karyawan Baru Menggunakan Metode Simple Additive Weighting (SAW) Di PT.TNA

Anik Sri Wahyuningsih, Yudhi Firmansyah

(Universitas Panca Sakti Bekasi ) 
Perancangan Sistem Informasi Pembayaran SPP Menggunakan Framework Laravel Ichwan Habib Moudi

(Universitas Panca Sakti Bekasi)

Implementasi Algoritma K-Means Dan Algoritma Apriori Optimasi Kinerja Ecu

(Study Kasus Mobil Avanza Dan Xenia)

Sigit Mintoro' Asep Afandi

(STMIK Dian Cipta Cendikia Kotabumi)

Sistem Pakar Penyakit Buah Kakao Untuk Peningkatan Hasil Panen Kakao Menggunakan

Metode Case Base Reasoning (CBR) Berbasis Web Mobile

Aliy hafiz, Verawati

(AMIK Dian Cipta Cendikia,Bandar Lampung)

Penerapan Metode Rapid Application Develomment (RAD) Dalam Pengembangan

Sistem Pemesanan Menu Berbasis Android

Aris Baihaqi, Tumini

(Fakultas Sains dan Teknologi ${ }^{1,2}$ )

Rancang Bangun Sistem Informasi Geografis Pariwisata Di Lampung Timur

Sukatmi, Rexa Alfa Rizi

(AMIK DCC Bandar Lampung ${ }^{12}$ )

Implementasi Psak No. 45 Pada Proses Penyusunan Laporan Keuangan Menggunakan

M.S. Excel Dan Aplikasi Accurate Accouting Pada STMIK Bani Saleh

Marhakim, Willy Adam

(STMIK Bani Saleh ${ }^{12}$ )

Sistem Prediksi Harga KOPI LAMBAR ( Lampung Barat) Dengan Metode

Backpropagation, dan Double Exponential ( Studi Kasus BUMDES )

Supriyanto, Dwi marisa Efendi,Rhomadhon

(STMIK Dian Cipta cendikia Kotabumi ${ }^{1-}$ )

Sistem Informasi Pemasaran Produk Umkm Berbasis Web Pada Kecamatan Bumi

Nabung Lampung Tengah

Yuli Syafitri, Agus Prasetyo, Reni Astika

(AMIK Dian Cipta Cendikia Bandar Lampung)

Rancang Bangun Aplikasi Pembelajaran Aksara Lampung Berbasis Android

Ferly Ardhy, Hendra Syahrobi

(Universitas Aisyah Pringewu ${ }^{1,}$ STMIK Dian Cipta Cendikia ${ }^{2}$ )

Sistem Pakar Diagnosa Penyakit Kulit Pada Balita Menggunakan Metode Naïve

Bayes Dan Forward Chaining Studi Kasus Puskesmas Cempaka Sungkai Selatan

Sidik Rahmatullah, Rima Mawarni

(STMIK Dian Cipta Cendikia Kotabumi ${ }^{12}$ )

Rekayasa Perangkat Lunak Perhitungan Harga Pokok Produksi Metode

Full Costing Pada Umkm Mitra Cake Di Bandar Lampung

Pitrawati, Arif Sanjaya

(AMIK Dian Cipta Cendikia, Bandar Lampung) 
Rancang Bangun Sistem Ujian Online Menggunakan Algoritma Cosine Similarity

Berbasis Web

Haryono, Zaenal Mutaqin Subekti, Widiyawati, Hidayatullah

(STMIK Bani Saleh ${ }^{1234}$ )

Model Aplikasi Helpdesk Ticketing System Berbasis Web Menggunakan Metode Rad Indra Permana

Pattern Recognition Tulisan Tangan Huruf Hijaiyah Menggunakan Metode

Convolutional Neural Network (CNN)

Mufassiril Abror, Nopiyanto

(Universitas Panca Sakti Bekasi ${ }^{12}$ )

Aplikasi Sistem Informasi Keuangan Berbasis Android Di Perumahan Taman

Karang Bahagia

Melda Ayulestari

(Universitas Panca Sakti Bekasi)

Audit Pelayanan Sistem Rujukan Online Puskesmas Menggunakan Framework COBIT 5.0

Nurmayanti, Merri Parida, Ngajiyanto, Ina Anzalna

(STMIK Dian Cipta Cendikia Kotabumi ${ }^{1234}$ )

Perancangan Sistem Informasi Pengolahan Data Nilai Siswa Berbasis Web

Erin Ermawati, Anik Sri Wahyuningsih

(Fakultas Sain dan Teknologi, Universitas Panca Sakti Bekasi ${ }^{12}$ )

Pengembangan Sistem Pelaporan Data Hasil Inspeksi Barang Berbasis Web

Siska Putriani

(Universitas Pancasakti Bekasi)

Penerapan Extreme Programming Dalam Perancangan Aplikasi Web Food Market

Tumini, Hilman Septiana

(Fakultas Sains dan Teknologi Universitas Panca Sakti Bekasi ${ }^{1,2}$ )

Sistem Pencarian Barang Berbasis Website Menggunakan Php Dan Mysql

Studi Kasus PT. Surya Technology Industri Sulaeman

(Universitas Panca Sakti Bekasi)

Implementasi Metode Prototype Pada Sistem Peminjaman Alat Kerja Berbasis Web

Di PT SK Metalindo

Ali Mulyanto, Arjun Gunawan

(Univeritas Panca Sakti Bekasi)

Aplikasi Tata Cara Wudhu Menggunakan Teknologi Augmented Reality

Sebagai Media Pembelajaran Di TK Al Fatih

Ahmad Yakub, Idarul Fadli

(Universitas Panca Sakti Bekasi ${ }^{12}$ )

Sistem Pakar Diagnosa Penyakit Ayam Petelur Menggunakan Metode Certainty Factor

Berbasis Web Mochammad

Taufiq Hidayat, Ali Mulyanto

(Universitas Panca Sakti Bekasi ${ }^{12}$ ) 
Penerapan Metode Prototyping Dalam Perhitungan Hasil Produksi Menggunakan Arduino Uno R3 Dan Php Di PT. Indonesia Epson Industry

Amandha Aulia, Ajar Rohmanu

(Universitas Panca Sakti Bekasi ${ }^{12}$ )

System Pendukung Keputusan Penentuan Guru Teladan Dengan Metode Profile Matching

Hasbulloh, Agmawarnida

(Universitas Panca Sakti Bekasi ${ }^{1,2}$ )

Implementasi Waterfall Method Pada Aplikasi Buku Induk Siswa Berbasis Web

Idam Holid, Yogie Krisnayadi

(Universitas Panca Sakti ${ }^{12}$ )

Pengembangan Text To Speech Media Pembelajaran Untuk Pengenalan

Anggota Tubuh Manusia Kelas V Sekolah Dasar

Juwanda Saputra, Ali Mulianto

(Teknik Infomratika Fakulutas Sains dan Teknologi ${ }^{12}$ )

Perancangan Sistem Peminjaman Barang Berupa Aset Tetap Berbasis Web

Pada Lembaga Permasyarakatan Kelas II A Banceuy Bandung

Guntur Salasa Priambodo, Perwito, Candra Mecca Sufyana

(Politeknik Piksi Ganesha Bandung ${ }^{1,2,3}$ )

Metode Pemilihan Karyawan Terbaik Sebagai Penentu Goodwill Perguruan Tinggi

Dengan Menggunakan Metode Topsis (Studi Kasus Perguruan Tinggi Di Lampung Utara)

Dwi Sartika, Pakarti Riswanto

(STMIK Dian Cipta Cendikia Kotabumi)

Sistem Pendukung Keputusan Pemilihan Merek Smartphone Menggunakan

Metode Analytical Hierarchy Process (AHP)

Ade Kiki Fatmawati, Muhammad Sultan Raflie, Norma Yunita

(Universitas Nusa Mandiri ${ }^{123}$ )

Pattern Recognition Aksara Lampung Menggunakan Algoritma Neural Network

Metode Analytical Hierarchy Process (AHP)

Nopiyanto, Rahmadi

(Universitas Panca Sakti Bekasi) 


\title{
SISTEM PENDUKUNG KEPUTUSAN PEMILIHAN MEREK SMARTPHONE MENGGUNAKAN METODE ANALYTICAL HIERARCHY PROCESS (AHP)
}

\author{
Ade Kiki Fatmawati ${ }^{1}$, Muhammad Sultan Raflie ${ }^{2}$, Norma Yunita ${ }^{3}$ \\ Universitas Nusa Mandiri ${ }^{123}$ \\ Jl. Kamal Raya RT/RW 01/06, Cengkareng Barat Kota Jakarta Barat 11730 \\ E-mail : Adekikifatmawati1@gmail.com¹, Raflienba22@gmail.com², Norma.nyt@nusamandiri@ac.id ${ }^{3}$
}

\begin{abstract}
ABSTRAK
Smartphone telah mengalami perkembangan yang sangat pesat pada saat ini. Baik dari segi Penyimpanan Memori, Baterai maupun design dan spesifikasi yang disajikan. Banyak macam merek smartphone yang menawarkan segala kelebihan-kelebihan dari sebuah smartphone. Maka dari itu penulis akan meneliti dan membandingkan beberapa dari kriteria smartphone yang dibutuhkan mahasiswa. Diharapkan dengan adanya penulisan ini dan penelitian ini dapat menambah wawasan bagi siapapun. Metode yang digunakan dalam penelitian ini adalah dengan menggunakan metode $A H P$ (Analytical Hierarchy Process) pendekatan. Penting sekali dalam pemilihan merek smartphone dikarenakan semakin bagus kualitas suatu merek smartphone akan akan timbul kepuasan terhadap mahasiswa. Dalam penelitian ini penulis mengambil empat kriteria pemilihan, yaitu Harga, Kapasitas Memori, Baterai dan Kamera.
\end{abstract}

Kata Kunci: Pemilihan Merek Smartphone, AHP (Analytical Hierarchy Process).

\section{ABSTRACTS}

Computers especially smartphones have experienced a very rapid development at this time. Both in terms of memory storage, battery and design and specifications are presented. Smartphones in its development undergoes a very rapid change. Many kinds of smartphone brands that offer all the advantages of a smartphone brand. Therefore the authers will examine and compare some of the criteria required smartphone students are expected with this writing and this research can add insight for anyone. The method used in this research is Analytical Hierarchy Process(AHP) method is very important approach in the selection of smartphone brand because the better quality of a brand of smartphone will arise satisfaction to student. In this study the outhors take four selection criteria, namely price, memory capacity, battery capacity and camera.

Keywords: Desicion Support system Of Smartphone brand, AHP (Analytical Hierarchy Process).

\section{PENDAhuluan}

Zaman sekarang smartphone menjadi teknologi yang perkembangannya semakin meningkat. Yang ada pada memori, baterai, juga model dan spesifikasi yang tersaji. Seberapa mampu smartphone juga berpengaruh pada harganya, semakin mahal harga sebuah smartphone, maka smartphone tersebut mempunyai kualitas terbaik. Banyaknya merek smartphone yang terdapat berbagai jenis smartphone yang menimbulkan competition teknologi untuk melengkapi kebutuhan manusia. Didasarkan pada banyak produk yang tersaji mulai berasal dari berbagai merek, spesifikasi, baterai, serta fungsional dari smartphone terkadang membuat 
seorang galau saat memilih smartphone yang dipilih. oleh sebab itu, saat ingin membeli smartphone wajib diadaptasi dengan kebutuhan.

Sistem pendukung keputusan ialah sebuah cara terbaik dan tindakan guna merampungkan suatu problem, sebagai akibatnya problem tersebut bisa terselesaikan secara efektif serta efesien. Sistem keputusan berfungsi pada suatu hal diantaranya, menjadi pengetahuan secara comprehensive terhadap problem, untuk memberikan kerangka fikir secara sistematis, mendapat pembinaan, Teknik yang diterapkan guna mengambil keputusan, dan menaikkan kualitas keputusan.

Pada saat ini terdapat berbagai jenis smartphone menggunakan beberapa detail spec yang dipasarkan menghasilkan pengguna sehingga

kesulitan pada kesesuaian pemilihan, menggunakan harapan dan aturan mereka. Sejalan dengan itu pula penggunaan smartphone pula semakin tinggi, sutau atri pada penggunaan handphone dalam menaikan keputusan terbaik dalam problem, pada hal tersebut artinya problem pemilihan smartphone. Berhubungan pada hal ini, maka dibuatlah suatu sistem pendukung keputusan pemilihan smartphone memakai metode Analitical Hierarcy Process (AHP), supaya pengguna dapat memilih pilihan smartphone dengan tepat sesuai dengan keinginan serta anggarannya.

Berbagai merek smartphone yang terdapat sekarang, penelitian diambil dari contoh merek smartphone yang banyak dibeli dan dicari oleh konsumen, diantaranya Iphone, Oppo, Vivo serta Xiaomi. Maka demikian akan diuji guna mengusut suatu merek smartphone yang ideal dan paling diminati pembeli di berbagai kalangan. Dengan demikian pembahasan penelitian ini ialah "Sistem Pendukung Keputusan Pemilihan Merek Smartphone memakai Metode Analytical Hierarchy Process (AHP)" Pilihan metode tersebut disebabkan oleh Metode Analytical Hierarchy Process
(AHP) yaitu model pendukung keputusan dimana komponen utamanya sebuah hirarki fungsional menggunakan input utamanya ialah persepsi manusia, yakni pada hal yang mengenal konflik smartphone.

\section{METODE PENELITIAN}

Metode penelitian yang digunakan penulis dalam penelitian ini adalah kuantitatif. Penelitian kuantitatif adalah jenis penelitian yang menggunakan desain penelitian mekanisme statistik atau metode kuantitatif lainnya untuk mengukur variabel penelitian.

Alat yang akan digunakan dalam penelitian ini adalah laporan lapangan sebagai sarana pengumpulan data dan studi referensi untuk melakukan penelitian. Suatu penelitian tentunya wajib dilakukan secara ilmiah dan sistematis. kabar lapangan sebagai forum pendataan yang efektif dan efisien karena mampu menaruh informasi yang relevan dan menyajikan data yang valid dan reliable yang nantinya akan diukur secara numerik.

Penulis melakukan penginputan data berdasarkan para narasumber memakai cara mengembangkan berita umum berjenis pertanyaan tertulis yang wajib dijawab atau dituliskan narasumber memakai prosedur pengisiannya. Kabar generik diberikan pada narasumber untuk diisi dengan sebenarnya menggunakan petunjuk dari peneliti, setelah terselesaikan responden akan mengembalikan berita umum yang telah diberikan tanggapan pada peneliti

\section{HASIL DAN PEMBAHASAN}

Pada artikel ini, penulis menggunakan aplikasi dasar metode Analytic Hierarchy Process (AHP) untuk menentukan hasil dan perdebatan penelitian. Prinsip dasarnya adalah dekomposisi, perbandingan, integrasi prioritas dan konsistensi. 


\section{a. Decompotion}

Mendefinisikan masalah yang kompleks, dan masalah direduksi menjadi masalah yang lebih kecil. Masalah dapat dibagi menjadi tiga bagian dengan tujuan, kriteria, dan alternatif, yang digambarkan dalam bentuk hierarki. Empat kriteria yang digunakan dalam evaluasi ini adalah harga, baterai, memori, dan kamera.

Harga sangat penting dalam memilih ponsel pintar, atau jumlah yang digunakan untuk mengukur nilai suatu barang. Dengan mencari tahu rincian harga, pengguna akan lebih memahami harga barang yang dijual.

Kapasitas baterai merupakan ukuran vitalitas atau besarnya energi yang dapat disimpan dalam sebuah ponsel pintar, sehingga memudahkan penggunanya untuk melakukan

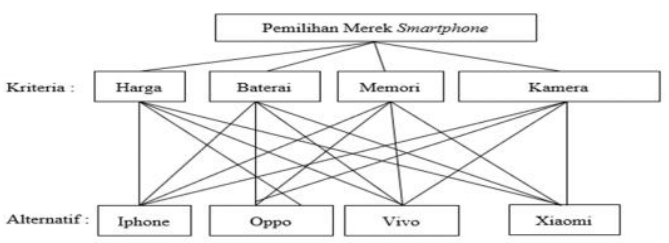

Gambar 1. Hirarki Perbandingan

Seperti yang ditunjukkan pada Gambar IV.1 di atas, ada empat kriteria perbandingan utama: harga, baterai, memori, dan kamera. Struktur hierarki di atas menggambarkan solusi masalah dan dibagi menjadi tiga bagian: tujuan, standar, dan alternatif. Tabel di bawah ini menunjukkan tiga item sebelumnya:

Tabel 1. Penjelasan Kriteria

\begin{tabular}{|c|c|l|}
\hline No & Kriteria & \multicolumn{1}{|c|}{ Penjelasan } \\
\hline 1 & Harga & $\begin{array}{l}\text { Menilai suatu harga per merek dan } \\
\text { tingkat kepuasan dalam pemilihan } \\
\text { Smartphone. }\end{array}$ \\
\hline 2 & Baterai & $\begin{array}{l}\text { Menilai besar kecilnya daya tahan } \\
\text { hidup pada Smartphone. }\end{array}$ \\
\hline 3 & Memori & $\begin{array}{l}\text { Menilai besar kecilnya Kamera } \\
\text { pada Smartphone. }\end{array}$ \\
\hline 4 & Kamera & Menilai kualitas resolusi kamera \\
\hline
\end{tabular}

berbagai aktivitas dalam kurun waktu tertentu. Memori internal smartphone.

Digunakan untuk menyimpan berbagai data. Semakin kecil isi memori yang tersimpan, semakin cepat kecepatan respon dan semakin cepat kinerjanya, yang tentunya akan menyebabkan aplikasi berjalan.

Kamera adalah seperangkat alat bawaan, digunakan sebagai alat untuk menghasilkan tampilan gambar, juga dapat merekam video. Menurut pengguna merek smartphone, dipilih responden, termasuk pelajar yang menggunakan smartphone sebagai alat yang diperlukan untuk berbagai aktivitas sehari-hari. Pembicara dipilih secara acak dalam proporsi yang sama

Kriteria dan alternative evaluasi dijelaskan dalam

Struktur hierarki berikut :

\section{b. Comparative}

Penilaian ini didasarkan pada kepentingan relatif dari dua faktor dari tingkat tertentu sehubungan dengan tingkat sebelumnya. Jika demikian, itu disebut matriks perbandingan berpasangan. Matriks perbandingan berpasangan dimasukkan dalam bentuk numerik untuk menunjukkan kepentingan relatif suatu item terhadap item lainnya. Nilai matriks perbandingan berpasangan diperoleh dari kuesioner yang diisi oleh responden. Dalam penelitian ini, penulis mengambil sampel 200 orang yang diwawancarai, berusia 17 hingga 35 tahun, yang tinggal di Jakarta Barat dan sekitarnya. Format kuesioner yang dibagikan pada responden ialah: (Lampiran A1)

Dalam pemilihan merek Smartphone, kriteria manakah yang lebih penting dibandingkan kriteria-kriteria berikut ini.

Tabel 2. Perbandingan berpasangan kriteria utama 


\begin{tabular}{|c|c|c|c|}
\hline \multicolumn{3}{|c|}{$\begin{array}{l}\text { Berdasarkan kriteria Utama. Alternatif } \\
\text { pemilihan merek Smartthone manakah } \\
\text { yang lebih penting dari perbandingan } \\
\text { berpasangan? }\end{array}$} & \multirow{2}{*}{\begin{tabular}{|l} 
Berapa tingkat kepentingannya \\
(1) (2) (3) (4) \\
\end{tabular}} \\
\hline Harga & & \begin{tabular}{|l|} 
Baterai \\
\end{tabular} & \\
\hline Harga & 00 & Memori & (1) (2) (3) (4) (5) (6) (1) (3) (9) \\
\hline Harga & 00 & Kamera & (1) (2) (3) (4) (5) (6) (1) (3) (4) \\
\hline Baterai & 00 & Memori & (1) (2) (3) (4) (5) (6) (1) (8) (9) \\
\hline Baterai & 00 & Kamera & (1) (2) (3) (4) (5) (6) (1) (3) (9) \\
\hline Memori & 00 & Kamera & (1) (2) (3) (4) (5) (6) (1) (8) (9) \\
\hline
\end{tabular}

Keterangan :

1 : Sama Pentingnya

3 : Sedikit Lebih Penting

5 : Lebih Penting Daripada

7 : Jauh Lebih Penting

9 : Mutlak Lebih Penting Daripada

2,4,6,8 : Nilai Antara Dua Pertimbangan

Tabel 3. Perbandingan berpasangan alternative berdasarkan kriteria "Harga"

\begin{tabular}{|l|l|l|l|l|}
\hline $\begin{array}{l}\text { Berdasarkan kriteria "Harga". Alternatif } \\
\text { pemilihan merek Smartphone manakah } \\
\text { yang lebih baik dari perbandingan } \\
\text { berpasangan? }\end{array}$ & \multicolumn{1}{l|}{ Berapa tingkat kepentingannya } \\
\hline Iphone & $\bigcirc$ & Oppo & (1) (2) (3) (4) (5) (6) (7) (8) (9) \\
\hline Iphone & $\bigcirc$ & Vivo & (1) (2) (3) (4) (5) (6) (7) (8) (9) \\
\hline Iphone & $\bigcirc$ & Xiaomi & (1) (2) (3) (4) (5) (6) (7) (8) (9) \\
\hline Oppo & $\bigcirc$ & Vivo & (1) (2) (3) (4) (5) (6) (7) (8) (9) \\
\hline Oppo & $\bigcirc$ & Xiaomi & (1) (2) (3) (4) (5) (6) (7) (8) (9) \\
\hline Vivo & $\bigcirc$ & Xiaomi & (1) (2) (3) (4) (5) (6) (7) (8) (9) \\
\hline
\end{tabular}

Tabel 4. Perbandingan berpasangan alternative berdasarkan kriteria "Baterai"

\begin{tabular}{|l|l|l|l|l|}
\hline $\begin{array}{l}\text { Berdasarkan kriteria "Baterai". Alternatif } \\
\text { pemilihan merek Smartphone manakah } \\
\text { yang daya tahannya lebih lama dari } \\
\text { perbandingan berpasangan? }\end{array}$ & Berapa tingkat kepentingannya \\
\hline Iphone & $\bigcirc$ & Oppo & (1) (2) (3) (4) (5) (6) (7) (8) (9) \\
\hline Iphone & $\bigcirc$ & Vivo & (1) (2) (3) (4) (5) (6) (7) (8) (9) \\
\hline Iphone & $\bigcirc$ & Xiaomi & (1) (2) (3) (4) (5) (6) (7) (8) (9) \\
\hline Oppo & $\bigcirc$ & Vivo & (1) (2) (3) (4) (5) (6) & (7) (8) (9) \\
\hline Oppo & $\bigcirc$ & Xiaomi & (1) (2) (3) (4) (5) (6) (7) (8) (9) \\
\hline Vivo & $\bigcirc$ & Xiaomi & (1) (2) (3) (4) (5) (6) (7) (8) (9) \\
\hline
\end{tabular}

Tabel 5. Perbandingan berpasangan alternative berdasarkan kriteria "Memori"

\begin{tabular}{|l|l|l|l|l|}
\hline $\begin{array}{l}\text { Berdasarkan kriteria "Memori". } \\
\text { Alternatif pemilihan merek Smartphone } \\
\text { manakah yang lebih besar kapasitasnya } \\
\text { dari perbandingan berpasangan? }\end{array}$ & \multicolumn{2}{l|}{ Berapa tingkat kepentingannya } \\
\hline Iphone & $\bigcirc$ & Oppo & (1) (2) (3) (4) (5) (6) (7) (8) (9) \\
\hline Iphone & $\bigcirc$ & Vivo & (1) (2) (3) (4) (5) (6) (7) (8) (9) \\
\hline Iphone & $\bigcirc$ & Xiaomi & (1) (2) (3) (4) (5) (6) (7) (8) (9) \\
\hline Oppo & $\bigcirc$ & Vivo & (1) (2) (3) (4) (5) (6) (7) (8) (9) \\
\hline Oppo & $\bigcirc$ & Xiaomi & (1) (2) (3) (4) (5) (6) (7) (8) (9) \\
\hline Vivo & $\bigcirc$ & Xiaomi & (1) (2) (3) (4) (5) (6) (7) (8) (9) \\
\hline
\end{tabular}

Tabel 6. Perbandingan berpasangan alternative berdasarkan kriteria "Kamera"

\begin{tabular}{|l|l|l|l|l|}
\hline $\begin{array}{l}\text { Berdasarkan kriteria "Kamera". } \\
\text { Alternatif pemilihan merek Smartphone } \\
\text { manakah yang lebih bagus kualitasnya } \\
\text { dari perbandingan berpasangan? }\end{array}$ & Berapa tingkat kepentingannya \\
\hline Iphone & $\bigcirc$ & Oppo & (1) (2) (3) (4) (5) (6) () (8) (9) \\
\hline Iphone & $\bigcirc$ & Vivo & (1) (2) (3) (4) (5) (6) (7) (8) (9) \\
\hline Iphone & $\bigcirc$ & Xiaomi & (1) (2) (3) (4) (5) (6) (7) (8) (9) \\
\hline Oppo & $\bigcirc$ & Vivo & (1) (2) (3) (4) (5) (6) (7) (8) (9) \\
\hline Oppo & $\bigcirc$ & Xiaomi & (1) (2) (3) (4) (5) (6) (7) (8) (9) \\
\hline Vivo & $\bigcirc$ & Xiaomi & (1) (2) (3) (4) (5) (6) (7) (8) (9) \\
\hline
\end{tabular}

Cara pengisian kuisioner adalah sebagai berikut:

1. Evaluasi bobot dilakukan dengan memberikan perbandingan berpasangan. Artinya, membandingkan kriteria evaluasi di sebelah kiri dengan evaluasi di sebelah kanan.

2. Jika skor kriteria di sebelah kiri lebih tinggi, kolom nilai di sebelah kiri digunakan, dan jika skor kriteria di sebelah kanan lebih tinggi, kolom nilai di sebelah kanan digunakan.

3. Meminta orang yang diwawancarai untuk melingkari pilihan nomor yang sesuai.

4. Gunakan evaluasi yang konsisten untuk setiap nilai yang diberikan.

5. Pilih menggunakan bilangan ganjil Jika ragu, Anda dapat mengatasi nilai perbandingan pentingnya faktor dengan mengisi bilangan genap di antara dua bilangan ganjil.

Data kuesioner yang telah diisi dan dikumpulkan, dirangkum kedalam 5 bentuk tabel-tabel perbandingan berpasangan yaitu:

\section{Tabel perbandingan berpasangan}

Berikut ini adalah perhitungan nilai rata-rata untuk masing-masing elemen kriteria utama: 
Tabel 7. Perbandingan Rata-Rata Kriteria Utama

Setelah menentukan perbandingan rata-rata

\begin{tabular}{|c|c|c|c|c|}
\hline \multicolumn{5}{|c|}{ TABEL PERBANDINGAN KRITERIA UTAMA } \\
\hline KRITERIA & HARGA & BATERAI & MEMORI & KAMERA \\
\hline HARGA & 1.00 & 0.48 & 0.34 & 3.06 \\
\hline BATERAI & 2.08 & 1.00 & 0.43 & 3.92 \\
\hline MEMORI & 2.94 & 2.33 & 1.00 & 2.76 \\
\hline KAMERA & 0.33 & 0.26 & 0.36 & 1.00 \\
\hline
\end{tabular}

elemen kriteria utama, selanjutnya menentukan nilai rata-rata dari perbandingan berpasangan kriteria Harga. Berikut adalah tabel perbandingan rata-rata untuk masing-masing kriteria elemen Harga:

Tabel 8. Perbandingan Rata-Rata Kriteria Harga

\begin{tabular}{|}
\begin{tabular}{|c|c|c|c|c|}
\hline \multicolumn{5}{|c|}{ TABEL PERBANDINGAN ALTERNATIF BERDASARKAN "HARGA" } \\
\hline KRITERIA & IPHONE & OPPO & VIVO & XIAOMI \\
\hline IPHONE & 1.00 & 0.83 & 0.58 & 0.73 \\
\hline OPPO & 1.21 & 1.00 & 0.38 & 0.44 \\
\hline VIVO & 1.72 & 2.63 & 1.00 & 0.51 \\
\hline XIAOMI & 1.38 & 2.25 & 1.95 & 1.00 \\
\hline
\end{tabular}
\end{tabular}

Selanjutnya menentukan nilai rata-rata pada kriteria Baterai dari perbandingan berpasangan kriteria. Berikut adalah tabel perhitungan ratarata untuk masing-masing kriteria elemen Baterai

Tabel 9. Perbandingan Rata-Rata Kriteria Baterai

\begin{tabular}{|}
\begin{tabular}{|c|c|c|c|c|}
\hline \multicolumn{1}{|c|}{ TABEL PERBANDINGAN ALTERNATIF BERDASARKAN "BATERAI" } \\
\hline KRITERIA & IPHONE & OPPO & VIVO & XIAOMI \\
\hline IPHONE & 1.00 & 0.40 & 0.67 & 0.66 \\
\hline OPPO & 2.50 & 1.00 & 2.07 & 0.49 \\
\hline VIVO & 1.50 & 0.48 & 1.00 & 0.78 \\
\hline XIAOMI & 1.51 & 2.04 & 1.29 & 1.00 \\
\hline
\end{tabular}
\end{tabular}

Selanjutnya menentukan nilai rata-rata pada kriteria Memori dari perbandingan berpasangan kriteria. Berikut adalah tabel perhitungan ratarata untuk masing-masing kriteria elemen Memori.

Tabel 10. Perbandingan Rata-Rata Kriteria Memori

\begin{tabular}{|c|c|c|c|c|}
\hline \multicolumn{5}{|c|}{ TABEL PERBANDINGAN ALTERNATIF BERDASARKAN "MEMORI" } \\
\hline KRITERIA & IPHONE & OPPO & VIVO & XIAOMI \\
\hline IPHONE & 1.00 & 1.88 & 3.22 & 1.41 \\
\hline OPPO & 0.53 & 1.00 & 2.83 & 0.37 \\
\hline VIVO & 0.31 & 0.35 & 1.00 & 0.36 \\
\hline XIAOMI & 0.71 & 2.72 & 2.78 & 1.00 \\
\hline
\end{tabular}

Selanjutnya menentukan nilai rata-rata pada kriteria Kamera dari perbandingan berpasangan kriteria. Berikut adalah tabel perhitungan ratarata untuk masing-masing kriteria elemen Kamera

Tabel 11. Perbandingan Rata-Rata Kriteria Kamera

\begin{tabular}{|c|c|c|c|c|}
\hline \multicolumn{5}{|c|}{ TABEL PERBANDINGAN ALTERNATIF BERDASARKAN "KAMERA" } \\
\hline KRITERIA & IPHONE & OPPO & VIVO & XIAOMI \\
\hline IPHONE & 1.00 & 1.19 & 1.72 & 1.19 \\
\hline OPPO & 0.84 & 1.00 & 2.28 & 1.16 \\
\hline VIVO & 0.58 & 0.44 & 1.00 & 0.67 \\
\hline XIAOMI & 0.84 & 0.87 & 1.50 & 1.00 \\
\hline
\end{tabular}

\section{c. Synthesis of priority}

Setelah membuat matriks perbandingan berpasangan, selanjutnya dilakukan pencarian nilai rata-rata (Vektor Eigen atau Local Priority). Proses tersebut dapat dilakukan dalam langkah sebagai berikut :

1. Menjumlahkan nilai dari setia kolom pada matriks.

2. Membagi setiap nilai dari kolom dengan total kolom yang bersangkutan untuk memperoleh normalisasi matriks.

3. Menjumlahkan nilai dari setiap baris dan dibagi dengan jumlah elemen untuk mendapatkan nilai rata-rata.

Sintesis dilakukan sebanyak jumlah matriks perbandingan yang telah dibuat, meliputi :
a. Level 1 berdasarkan kriteria utama.
b. Level 2 berdasarkan kriteria harga
c. Level 3 berdasarkan kriteria baterai
d. Level 4 berdasarkan kriteria memori
e. Level 5 berdasarkan kriteria kamera

Sintesis Level 1 Berdasarkan Kriteria Utama 
Tabel 12. Penjumlahan Nilai Kolom Kriteria Utama

\begin{tabular}{|c|c|c|c|c|}
\hline \multicolumn{5}{|c|}{ TABEL PERBANDINGAN KRITERIA UTAMA } \\
\hline KRITERIA & HARGA & BATERAI & MEMORI & KAMERA \\
\hline HARGA & 1.00 & 0.48 & 0.34 & 3.06 \\
\hline BATERAI & 2.08 & 1.00 & 0.43 & 3.92 \\
\hline MEMORI & 2.94 & 2.33 & 1.00 & 2.76 \\
\hline KAMERA & 0.33 & 0.26 & 0.36 & 1.00 \\
\hline JUMLAH & 14.00 & 6.58 & 1.78 & 8.17 \\
\hline
\end{tabular}

Selanjutnya menormalisasikan matriks perbandingan berpasangan dengan membagikan nilai-nilai pada setiap sel dengan total nilai pada kolom yang bersangkutan.

Tabel 13. Normalisasi Kriteria Utama

\begin{tabular}{|c|c|c|c|}
\hline \multicolumn{4}{|c|}{ NILAI EIGEN } \\
\hline HARGA & BATERAI & MEMORI & KAMERA \\
\hline 0.16 & 0.12 & 0.16 & 0.28 \\
\hline 0.33 & 0.25 & 0.20 & 0.36 \\
\hline 0.46 & 0.57 & 0.47 & 0.26 \\
\hline 0.05 & 0.06 & 0.17 & 0.09 \\
\hline
\end{tabular}

Tabel 14. Faktor Eign Kriteria Utama

\begin{tabular}{|c|c|c|c|c|c|}
\hline \multicolumn{5}{|c|}{ NILAI EIGEN } \\
\hline HARGA & BATERAI & MEMORI & KAMERA & JUMLAH & RATA-RATA \\
\hline 0.16 & 0.12 & 0.16 & 0.28 & 0.72 & 0.179854 \\
\hline 0.33 & 0.25 & 0.20 & 0.36 & 1.14 & 0.284917 \\
\hline 0.46 & 0.57 & 0.47 & 0.26 & 1.76 & 0.440885 \\
\hline 0.05 & 0.06 & 0.17 & 0.09 & 0.38 & 0.094344 \\
\hline
\end{tabular}

Dari tabel diatas terlihat bahwa:

a. Kriteria Harga memiliki prioritas ketiga dengan bobot 0,18

b. Kriteria Baterai memiliki prioritas kedua dengan bobot 0,28

c. Kriteria Memori memiliki prioritas tertinggi dengan bobot 0,44

d. Kriteria Kamera memiliki prioritas terendah dengan bobot 0,09

Sehingga urutan kriteria untuk penetapan penilaian pemilihan merek Smartphone adalah:
1. Memori
2. Baterai
3. Harga
4. Kamera

Sintesis Level 2 Berdasarkan Kriteria Elemen Harga

Tabel 15. Penjumlahan Nilai Kolom Kriteria Harga

\begin{tabular}{|c|c|c|c|c|}
\hline \multicolumn{5}{|c|}{ TABEL PERBANDINGAN ALTERNATIF BERDASARKAN "HARGA" } \\
\hline KRITERIA & IPHONE & OPPO & VIVO & XIAOMI \\
\hline IPHONE & 1.00 & 0.83 & 0.58 & 0.73 \\
\hline OPPO & 1.21 & 1.00 & 0.38 & 0.44 \\
\hline VIVO & 1.72 & 2.63 & 1.00 & 0.51 \\
\hline XIAOMI & 1.38 & 2.25 & 1.95 & 1.00 \\
\hline JUMLAH & 5.31 & 6.70 & 3.91 & 2.68 \\
\hline
\end{tabular}

Selanjutnya menormalisasikan matriks perbandingan berpasangan dengan cara membagi nilai-nilai pada setiap sel dengan total nilai pada kolom yang bersangkutan.

Tabel 16. Normalisasi Kriteria Harga

\begin{tabular}{|c|c|c|c|}
\hline \multicolumn{5}{|c|}{ NILAI EIGEN } \\
\hline IPHONE & OPPO & VIVO & XIAOMI \\
\hline 0.19 & 0.12 & 0.15 & 0.27 \\
\hline 0.23 & 0.15 & 0.10 & 0.17 \\
\hline 0.32 & 0.39 & 0.26 & 0.19 \\
\hline 0.26 & 0.34 & 0.50 & 0.37 \\
\hline
\end{tabular}

Tabel 17. Vektor Eigen Kriteria Harga

\begin{tabular}{|c|c|c|c|c|c|}
\hline \multicolumn{7}{|c|}{ NILAI EIGEN } \\
\hline IPHONE & OPPO & VIVO & XIAOMI & JUMLAH & RATA-RATA \\
\hline 0.19 & 0.12 & 0.15 & 0.27 & 0.73 & 0.18282 \\
\hline 0.23 & 0.15 & 0.10 & 0.17 & 0.64 & 0.159968 \\
\hline 0.32 & 0.39 & 0.26 & 0.19 & 1.16 & 0.290645 \\
\hline 0.26 & 0.34 & 0.50 & 0.37 & 1.47 & 0.366567 \\
\hline
\end{tabular}

Dari tabel diatas terlihat bahwa:

a. Alternatif merek Iphone memiliki prioritas ketiga dengan bobot 0,18

b. Alternatif merek Oppo memiliki prioritas terendah dengan bobot 0,16

c. Alternatif merek Vivo memiliki prioritas kedua dengan bobot 0,29

d. Alternatif merek Xiaomi memiliki prioritas tertinggi dengan bobot 0,37

Sehingga urutan kriteria untuk penetapan penilaian pemilihan merek Smartphone adalah:

1. Xiaomi

2. Vivo

3. Iphone

4. Oppo 
Sintesis Level 3 Berdasarkan Kriteria Elemen Baterai

Tabel 18. Penjumlahan Nilai Kolom Kriteria Baterai

\begin{tabular}{|c|c|c|c|c|}
\hline \multicolumn{5}{|c|}{ TABEL PERBANDINGAN ALTERNATIF BERDASARKAN "BATERAI" } \\
\hline KRITERIA & IPHONE & OPPO & VIVO & XIAOMI \\
\hline IPHONE & 1.00 & 0.40 & 0.67 & 0.66 \\
\hline OPPO & 2.50 & 1.00 & 2.07 & 0.49 \\
\hline VIVO & 1.50 & 0.48 & 1.00 & 0.78 \\
\hline XIAOMI & 1.51 & 2.04 & 1.29 & 1.00 \\
\hline JUMLAH & 6.51 & 3.92 & 5.03 & 2.93 \\
\hline
\end{tabular}

Selanjutnya menormalisasikan matriks perbandingan berpasangan dengan cara membagi nilai-nilai pada setiap sel dengan total nilai pada kolom yang bersangkutan.

Tabel 19. Normalisasi Kriteria Baterai

\begin{tabular}{|c|c|c|c|}
\hline \multicolumn{5}{|c|}{ NILAI EIGEN } \\
\hline IPHONE & OPPO & VIVO & XIAOMI \\
\hline 0.15 & 0.10 & 0.13 & 0.23 \\
\hline 0.38 & 0.26 & 0.41 & 0.17 \\
\hline 0.23 & 0.12 & 0.20 & 0.26 \\
\hline 0.23 & 0.52 & 0.26 & 0.34 \\
\hline
\end{tabular}

Tabel 20. Vektor Eigen Kriteria Baterai

\begin{tabular}{|c|c|c|c|c|c|}
\hline \multicolumn{7}{|c|}{ NILAI EIGEN } \\
\hline IPHONE & OPPO & VIVO & XIAOMI & JUMLAH & RATA-RATA \\
\hline 0.15 & 0.10 & 0.13 & 0.23 & 0.61 & 0.153541 \\
\hline 0.38 & 0.26 & 0.41 & 0.17 & 1.22 & 0.304779 \\
\hline 0.23 & 0.12 & 0.20 & 0.26 & 0.82 & 0.204288 \\
\hline 0.23 & 0.52 & 0.26 & 0.34 & 1.35 & 0.337392 \\
\hline
\end{tabular}

Dari tabel diatas terlihat bahwa:

a. Alternatif merek Iphone memiliki prioritas terendah dengan bobot 0,15

b. Alternatif merek Oppo memiliki prioritas kedua dengan bobot 0,30

c. Alternatif merek Vivo memiliki prioritas ketiga dengan bobot 0,20

d. Alternatif merek Xiaomi memiliki prioritas tertinggi dengan bobot 0,34

Sehingga urutan kriteria untuk penetapan penilaian pemilihan merek Smartphone adalah:

1. Xiaomi

2. Oppo
3. Vivo

4. Iphone

Sintesis Level 4 Berdasarkan Kriteria Elemen Memori

Tabel 21. Penjumlaahan Nilai Kolom Kriteria Memori

\begin{tabular}{|c|c|c|c|c|}
\hline \multicolumn{5}{|c|}{ TABEL PERBANDINGAN ALTERNATIF BERDASARKAN "MEMORI" } \\
\hline KRITERIA & IPHONE & OPPO & VIVO & XIAOMI \\
\hline IPHONE & 1.00 & 1.88 & 3.22 & 1.41 \\
\hline OPPO & 0.53 & 1.00 & 2.83 & 0.37 \\
\hline VIVO & 0.31 & 0.35 & 1.00 & 0.36 \\
\hline XIAOMI & 0.71 & 2.72 & 2.78 & 1.00 \\
\hline JUMLAH & 2.55 & 5.95 & 9.83 & 3.13 \\
\hline
\end{tabular}

Selanjutnya menormalisasikan matriks perbandingan berpasangan dengan cara membagi nilai-nilai pada setiap sel dengan total nilai pada kolom yang bersangkutan.

Tabel 22. Normalisasi Kriteria Memori

\begin{tabular}{|c|c|c|c|}
\hline \multicolumn{5}{|c|}{ NILAI EIGEN } \\
\hline IPHONE & OPPO & VIVO & XIAOMI \\
\hline 0.39 & 0.32 & 0.33 & 0.45 \\
\hline 0.21 & 0.17 & 0.29 & 0.12 \\
\hline 0.12 & 0.06 & 0.10 & 0.11 \\
\hline 0.28 & 0.46 & 0.28 & 0.32 \\
\hline
\end{tabular}

Tabel 23. Vektor Eigen Kriteria Memori

\begin{tabular}{|c|c|c|c|c|c|}
\hline \multicolumn{5}{|c|}{ NILAI EIGEN } \\
\hline IPHONE & OPPO & VIVO & XIAOMI & JUMLAH & RATA-RATA \\
\hline 0.39 & 0.32 & 0.33 & 0.33 & 1.48 & 0.37082 \\
\hline 0.21 & 0.17 & 0.17 & 0.29 & 0.78 & 0.195547 \\
\hline 0.12 & 0.06 & 0.06 & 0.10 & 0.40 & 0.099339 \\
\hline 0.28 & 0.46 & 0.46 & 0.28 & 1.34 & 0.334293 \\
\hline
\end{tabular}

Dari tabel diatas terlihat bahwa:

a. Alternatif merek Iphone memiliki prioritas tertinggi dengan bobot 0,37

b. Alternatif merek Oppo memiliki prioritas ketiga dengan bobot 0,20

c. Alternatif merek Vivo memiliki prioritas terendah dengan bobot 0,10

d. Alternatif merek Xiaomi memiliki prioritas kedua dengan bobot 0,33

Sehingga urutan kriteria untuk penetapan penilaian pemilihan merek Smartphone adalah:

1. Iphone

2. Xiaomi

3. Oppo

4. Vivo 
Sintesis Level 5 Berdasarkan Kriteria Elemen Kamera

Tabel 24. Penjumlaahan Nilai Kolom Kriteria Kamera

\begin{tabular}{|c|c|c|c|c|}
\hline \multicolumn{5}{|c|}{ TABEL PERBANINGAN ALTERNATIF BERDASARKAN "KAMERA" } \\
\hline KRITERIA & IPHONE & OPPO & VIVO & XIAOMI \\
\hline IPHONE & 1.00 & 1.19 & 1.72 & 1.19 \\
\hline OPPO & 0.84 & 1.00 & 2.28 & 1.16 \\
\hline VIVO & 0.58 & 0.44 & 1.00 & 0.67 \\
\hline XIAOMI & 0.84 & 0.87 & 1.50 & 1.00 \\
\hline JUMLAH & 3.27 & 3.49 & 6.50 & 4.01 \\
\hline
\end{tabular}

Selanjutnya menormalisasikan matriks perbandingan berpasangan dengan cara membagi nilai-nilai pada setiap sel dengan total nilai pada kolom yang bersangkutan.

Tabel 25. Normalisasi Kriteria Kamera

\begin{tabular}{|c|c|c|c|}
\hline \multicolumn{4}{|c|}{ NILAI EIGEN } \\
\hline IPHONE & OPPO & VIVO & XIAOMI \\
\hline 0.31 & 0.34 & 0.26 & 0.30 \\
\hline 0.26 & 0.29 & 0.35 & 0.29 \\
\hline 0.18 & 0.13 & 0.15 & 0.17 \\
\hline 0.26 & 0.25 & 0.23 & 0.25 \\
\hline
\end{tabular}

Tabel 26. Vektor Eigen Kriteria Kamera

\begin{tabular}{|c|c|c|c|c|c|}
\hline \multicolumn{5}{|c|}{ NILAI EIGEN } \\
\hline IPHONE & OPPO & VIVO & XIAOMI & JUMLAH & RATA-RATA \\
\hline 0.31 & 0.34 & 0.26 & 0.30 & 1.21 & 0.301581 \\
\hline 0.26 & 0.29 & 0.35 & 0.29 & 1.18 & 0.295881 \\
\hline 0.18 & 0.13 & 0.15 & 0.17 & 0.62 & 0.155921 \\
\hline 0.26 & 0.25 & 0.23 & 0.25 & 0.99 & 0.246618 \\
\hline
\end{tabular}

Dari tabel diatas terlihat bahwa:
a. Alternatif merek Iphone memiliki prioritas tertinggi dengan bobot $0,30(0,302)$
b. Alternatif merek Oppo memiliki prioritas kedua dengan bobot $0,30(0,296)$
c. Alternatif merek Vivo memiliki prioritas ketiga dengan bobot 0,16
d. Alternatif merek Xiaomi memiliki prioritas terendah dengan bobot 0,25

Jadi urutan kriteria untuk penetapan penilaian pemilihan merek Smartphone adalah:
1. Iphone
2. Oppo
3. Xiaomi
4. Vivo

\subsection{Consistency}

Pada tahap ini akan menentukan valid tidaknya Vektor Eigen yang diperoleh dari proses Synthesis Of Priority yang telah dibuat pada proses sebelumnya.

\section{Level 1 Berdasarkan Kriteria Utama}

Berikut adalah langkah menghitung $\lambda$ maksimum:

a. Mengalikan matriks perbandingan berpasangan yang belum dinormalisasikan dengan Vektor Eigen (Nilai Rata-rata)

$$
\left(\begin{array}{llll}
1,00 & 0,48 & 0,34 & 3,06 \\
2,08 & 1,00 & 0,43 & 3,92 \\
2,94 & 2,33 & 1,00 & 2,76 \\
0,33 & 0,26 & 0,36 & 1,00
\end{array}\right) \times\left(\begin{array}{l}
0,18 \\
0,28 \\
0,44 \\
0,09
\end{array}\right)=\left(\begin{array}{l}
0,535 \\
0,859 \\
1,451 \\
1,358
\end{array}\right)
$$

Gambar 2. Vektor Eigen (Nilai Rata-rata)

b. Hasil perkaliannya dibagi dengan Vektor

$$
\begin{aligned}
& \left(\begin{array}{l}
0,535 \\
0,859 \\
1,451 \\
1,358
\end{array}\right) \div\left(\begin{array}{l}
0,18 \\
0,28 \\
0,44 \\
0,09
\end{array}\right)=\left(\begin{array}{l}
4,129 \\
4,109 \\
4,189 \\
4,315
\end{array}\right) \\
& \text { Eigen }
\end{aligned}
$$

Gambar 3. Vektor Eigen

c. Bagi skala hasil operasi penjumlahan tersebut dengan banyaknya baris atau kolom. Hasil akhir dijadikan sebagai $\lambda$ maksimum. $(4,129+4,109+4,189+$ $4,315) / 4=4,254$

Langkah selanjutnya dari Consistency yaitu dengan menguji konsistensi hirarki dengan cara sebagai berikut :

a. Menghitung indeks konsistensi $($ Consistency Index $=\mathrm{CI})$ Rumus : $\mathrm{CI}=(\lambda$ maks $-\mathrm{N}) /(\mathrm{N}-1)$

$\mathrm{N}$ adalah jumlah baris atau kolom matriks perbandingan berpasangan

$(4.254-4) /(4-1)=0,085$ 
b. Menghitung rasio konsistensi (Consistency

Ratio $=\mathrm{CR})$

Rumus : $\mathrm{CR}=\mathrm{CI} / \mathrm{RI}$

Dimana RI adalah nilai acak yang diperoleh dari tabel Random Consistency Index pada N tertentu.

\begin{tabular}{|l|l|l|l|l|l|l|l|l|l|l|}
\hline $\mathrm{N}$ & 1 & 2 & 3 & 4 & 5 & 6 & 7 & 8 & 9 & 10 \\
\hline $\mathrm{RI}$ & 0 & 0 & 0,58 & 0,90 & 1,12 & 1,24 & 1,32 & 1,41 & 1,45 & 1,49 \\
\hline
\end{tabular}

$\mathrm{CR}=(0,085 / 0,90)=0.094$

Karena nilai $\mathrm{CR}<0,1 \quad(10 \%)$ maka dapat diterima, artinya matrix perbandingan berpasangan Level 1 berdasarkan kriteria utama telah diisi dengan pertimbangan yang konsisten dan Vektor Eigen yang dihasilkan dapat diandalkan.

Level 2 Berdasarkan Elemen Kriteria Harga

Berikut adalah langkah menghitung $\lambda$ maksimum:

a. Mengalikan matriks perbandingan berpasangan yang belum dinormalisasikan dengan Vektor Eigen (Nilai Rata-rata)

$\left(\begin{array}{llll}1,00 & 0,83 & 0,58 & 0,73 \\ 1,21 & 1,00 & 0,38 & 0,44 \\ 1,72 & 2,63 & 1,00 & 0,51 \\ 1,38 & 2,25 & 1,95 & 1,00\end{array}\right) \times\left(\begin{array}{l}0,18 \\ 0,16 \\ 0,29 \\ 0,37\end{array}\right)=\left(\begin{array}{l}0,535 \\ 0,859 \\ 1,451 \\ 1,358\end{array}\right)$

Gambar 4. Vektor Eigen

b. sil perkaliannya dibagi dengan Vektor

$$
\left(\begin{array}{l}
0,535 \\
0,859 \\
1,451 \\
1,358
\end{array}\right) \div\left(\begin{array}{l}
0,18 \\
0,16 \\
0,29 \\
0,37
\end{array}\right)=\left(\begin{array}{l}
4,184 \\
4,506 \\
4,237 \\
4,109
\end{array}\right)
$$

Eigen (Nilai Rata-rata)

Gambar 5. Vektor Eigen

c. Bagi skala hasil operasi penjumlahan tersebut dengan banyaknya baris atau kolom. Hasil akhir dijadikan sebagai $\lambda$ maksimum.

$(4,184+4,506+4,237+4,109) / 4=4,164$ Langkah selanjutnya dari Consistency yaitu dengan menguji konsistensi hirarki dengan cara sebagai berikut:

a. Menghitung indeks konsistensi $($ Consistency Index = CI)
Rumus : $\mathrm{CI}=(\lambda$ maks $-\mathrm{N}) /(\mathrm{N}-1)$

$\mathrm{N}$ adalah jumlah baris atau kolom matriks perbandingan berpasangan $(4,164-4) /(4-1)=0,055$.

b. Menghitung rasio konsistensi $($ Consistency Ratio $=\mathrm{CR})$

Rumus : $\mathrm{CR}=\mathrm{CI} / \mathrm{RI}$

Dimana RI merupakan nilai acak yang diperoleh dari tabel Random Consistency Index pada $\mathrm{N}$ tertentu.

\begin{tabular}{|l|l|l|l|l|l|l|l|l|l|l|}
\hline & 1 & 2 & 3 & 4 & 5 & 6 & 7 & 8 & 9 & 10 \\
\hline $\mathrm{I}$ & 0 & 0 & 0,58 & 9,90 & 1,12 & 1,24 & 1,32 & 1,41 & 1,45 & 1,49 \\
\hline
\end{tabular}

$\mathrm{CR}=(0,055 / 0,90)=0,061$

Karena nilai $\mathrm{CR}<0,1$ (10\%) maka dapat diterima, artinya matrix perbandingan berpasangan Level 1 berdasarkan kriteria utama telah diisi dengan

pertimbangan yang konsisten dan Vektor Eigen yang dihasilkan dapat diandalkan.

\section{Level 3 Berdasarkan Elemen Kriteria Baterai}

Berikut adalah langkah menghitung $\lambda$ maksimum:

a. Mengalikan matriks perbandingan berpasangan yang belum dinormalisasikan

$$
\begin{gathered}
\left(\begin{array}{cccc}
1,00 & 0,40 & 0,67 & 0,66 \\
2,50 & 1,00 & 2,07 & 0,49 \\
1,50 & 0,48 & 1,00 & 0,78 \\
1,51 & 2,04 & 1,29 & 1,00
\end{array}\right) \times\left(\begin{array}{l}
0,15 \\
0,30 \\
0,20 \\
0,34
\end{array}\right)=\left(\begin{array}{l}
1,169 \\
1,575 \\
0,860 \\
0,436
\end{array}\right) \\
\text { dengan Vektor Eigen (Nilai Rata-rata) } \\
\text { Gambar 6. Vektor Eigen }
\end{gathered}
$$

b. Hasil perkaliannya dibagi dengan Vektor

$$
\left(\begin{array}{l}
1,169 \\
1,575 \\
0,860 \\
0,436
\end{array}\right) \div\left(\begin{array}{l}
0,15 \\
0,30 \\
0,20 \\
0,34
\end{array}\right)=\left(\begin{array}{l}
4,044 \\
4,054 \\
4,024 \\
4,021
\end{array}\right)
$$

Eigen (Nilai Rata-rata)

Gambar 7. Vektor Eigen

c. Bagi skala hasil operasi penjumlahan tersebut dengan banyaknya baris atau kolom. Hasil akhir dijadikan sebagai $\lambda$ maksimum.

$(4,044+4,054+4,024+4,021) / 4=4,210$ 
Langkah selanjutnya dari Consistency yaitu dengan menguji konsistensi hirarki dengan cara sebagai berikut:

a. Menghitung indeks konsistensi (Consistency Index $=\mathrm{CI}$ )

Rumus : $\mathrm{CI}=(\lambda$ maks $-\mathrm{N}) /(\mathrm{N}-1)$

$\mathrm{N}$ adalah jumlah baris atau kolom matriks perbandingan berpasangan $(4,210-4) /(4-1)=0,070$

b. Menghitung rasio konsistensi $($ Consistency Ratio $=\mathrm{CR})$

Rumus : CR $=\mathrm{CI} / \mathrm{RI}$

Dimana RI merupakan nilai acak yang diperoleh dari tabel Random Consistency Index pada $\mathrm{N}$ tertentu

$\mathrm{CR}=(0,070 / 0,90)=0,078$

Karena nilai $\mathrm{CR}<0,1 \quad(10 \%)$ maka dapat diterima, artinya matrix perbandingan berpasangan Level 1 berdasarkan kriteria utama telah diisi dengan pertimbangan yang konsisten

\begin{tabular}{|l|l|l|l|l|l|l|l|l|l|l|}
\hline & 1 & 2 & 3 & 4 & 5 & 6 & 7 & 8 & 9 & 10 \\
\hline I & 0 & 0 & 0,58 & 0,90 & 1,12 & 1,24 & 1,32 & 1,41 & 1,45 & 1,49 \\
\hline
\end{tabular}

dan Vektor Eigen yang dihasilkan dapat diandalkan.

Level 4 Berdasarkan Elemen Kriteria Memori

Berikut adalah langkah menghitung $\lambda$ maksimum:

a. Mengalikan matriks perbandingan berpasangan yang belum dinormalisasikan $\left(\begin{array}{llll}1,00 & 1,88 & 3,22 & 1,41 \\ 0,53 & 1,00 & 2,83 & 0,37 \\ 0,31 & 0,35 & 1,00 & 0,36 \\ 0,71 & 2,72 & 2,78 & 1,00\end{array}\right) \times\left(\begin{array}{c}0,37 \\ 0,20 \\ 0,10 \\ 0,33\end{array}\right)=\left(\begin{array}{c}1,516 \\ 1,265 \\ 0,785 \\ 0,465\end{array}\right)$ dengan Vektor Eigen (Nilai Rata-rata)

Gambar 8. Vektor Eigen

$\left(\begin{array}{llll}1,00 & 1,19 & 1,72 & 1,19 \\ 0,84 & 1,00 & 2,28 & 1,16 \\ 0,58 & 0,44 & 1,00 & 0,67 \\ 0,84 & 0,87 & 1,50 & 1,00\end{array}\right) \times\left(\begin{array}{l}0,30 \\ 0,30 \\ 0,16 \\ 0,25\end{array}\right)=\left(\begin{array}{l}0,926 \\ 1,432 \\ 1,172 \\ 0,498\end{array}\right)$

b. Hasil perkaliannya dibagi dengan Vektor Eigen (Nilai Rata-rata) c. Bagi skala hasil operasi penjumlahan

$\left(\begin{array}{l}1,516 \\ 1,265 \\ 0,785 \\ 0,465\end{array}\right) \div\left(\begin{array}{l}0,37 \\ 0,20 \\ 0,10 \\ 0,33\end{array}\right)=\left(\begin{array}{l}4,038 \\ 4,033 \\ 4,036 \\ 4,016\end{array}\right)$

Gambar 9. Vektor Eigen

d. tersebut dengan banyaknya baris atau kolom. Hasil akhir dijadikan sebagai $\lambda$ maksimum.

$(4,038+4,033+4,036+4,016) / 4=4,135$ Langkah selanjutnya dari Consistency yaitu dengan menguji konsistensi hirarki dengan cara sebagai berikut:

\begin{tabular}{|l|l|l|l|l|l|l|l|l|l|l|}
\hline & 1 & 2 & 3 & 4 & 5 & 6 & 7 & 8 & 9 & 10 \\
\hline $\mathrm{I}$ & 0 & 0 & 0,58 & 0,90 & 1,12 & 1,24 & 1,32 & 1,41 & 1,45 & 1,49 \\
\hline
\end{tabular}

a. Menghitung indeks konsistensi (Consistency Index $=\mathrm{CI}$ )

Rumus : $\mathrm{CI}=(\lambda$ maks $-\mathrm{N}) /(\mathrm{N}-1)$

$\mathrm{N}$ adalah jumlah baris atau kolom matriks perbandingan berpasangan $(4,135-4) /(4-1)=0,045$

b. Menghitung rasio konsistensi $($ Consistency Ratio $=\mathrm{CR})$

Rumus : CR = CI / RI

Dimana RI merupakan nilai acak yang diperoleh dari tabel Random Consistency Index pada $\mathrm{N}$ tertentu.

$\mathrm{CR}=(0,045 / 0,90)=0,050$

Karena nilai $\mathrm{CR}<0,1 \quad(10 \%)$ maka dapat diterima, artinya matrix perbandingan berpasangan Level 1 berdasarkan kriteria utama telah diisi dengan pertimbangan yang konsisten dan Vektor Eigen yang dihasilkan dapat diandalkan.

Level 5 Berdasarkan Elemen Kriteria Kamera Berikut adalah langkah menghitung $\lambda$ maksimum:

a. Mengalikan matriks perbandingan berpasangan yang belum dinormalisasikan dengan Vektor Eigen (Nilai Rata-rata) Gambar 10. Vektor Eigen

b. Hasil perkaliannya dibagi dengan Vektor Eigen (Nilai Rata-rata) 


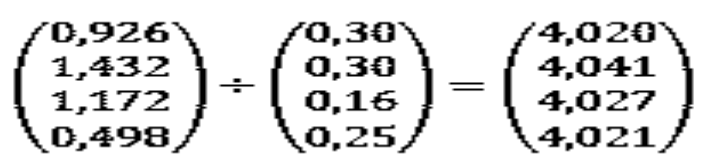

Gambar 11. Vektor Eigen

c. Bagi skala hasil operasi penjumlahan tersebut dengan banyaknya baris atau kolom. Hasil akhir dijadikan sebagai $\lambda$ maksimum.

$(4,020+4,041+4,027+4,021) / 4=4,020$ Langkah selanjutnya dari Consistency yaitu dengan menguji konsistensi hirarki dengan cara sebagai berikut:

a. Menghitung indeks konsistensi

(Consistency Index $=\mathrm{CI}$ )

Rumus : $\mathrm{CI}=(\lambda$ maks $-\mathrm{N}) /(\mathrm{N}-1)$

$\mathrm{N}$ adalah jumlah baris atau kolom matriks perbandingan berpasangan

$(4,020-4) /(4-1)=0,007$

b. Menghitung rasio konsistensi

$($ Consistency Ratio = CR $)$

Rumus : CR = CI / RI

Dimana RI merupakan nilai acak yang diperoleh dari tabel Random Consistency Index pada $\mathrm{N}$ tertentu.

$\mathrm{CR}=(0,007 / 0,90)=0,007$

Karena nilai $\mathrm{CR}<0,1 \quad(10 \%)$ maka dapat diterima, artinya matrix perbandingan berpasangan Level 1 berdasarkan kriteria utama telah diisi dengan pertimbangan yang konsisten dan Vektor Eigen yang dihasilkan dapat diandalkan.

\section{KESIMPULAN}

Berdasarkan pengamatan dan analisis pengolahan data pada bab sebelumnya, penulis dapat menarik kesimpulan:

1. Penulis memakai metode AHP (Analytical Hierarchy Process) untuk sistem penunjang keputusan pemilihan merek smartphone untuk mahasiswa.

2. Selama dilakukannya Analisa ini, penulis memakai sampel berdasarkan dari mahasiswa.
3. Pada pengolahan data, terdapat empat kriteria (Harga, Kapasitas Baterai, Kapasitas Memori, dan Kamera) dan tiga alternatif ialah (Iphone, Oppo, Vivo, Xiaomi).

4. Proses dan analisis data orang yang diwawancarai, dan didapatkan hasil sebagai berikut:

a. Merek dari smartphone Iphone mempunyai bobot prioritas ketiga yaitu $0,032=32 \%$

b. Merek dari smartphone Oppo mempunyai bobot teratas ialah : 0,058 $=58 \%$

c. Merek dari smartphone Vivo mempunyai bobot Kedua yaitu : 0,053 $=53 \%$

d. Merek dari smartphone Xiaomi mempunyai bobot terbawah yaitu : $0,22=22 \%$ Hasil perhitungan nilai merek smartphone OPPO tertinggi yaitu $58 \%$.

5. CR mengasumsikan bahwa hasilnya menunjukkan bahwa nilainya kurang dari 0,1 atau kurang dari $10 \%$, dan hierarki umum konsisten, sehingga kesimpulan

\begin{tabular}{|l|l|l|l|l|l|l|l|l|l|l|}
\hline & 1 & 2 & 3 & 4 & 5 & 6 & 7 & 8 & 9 & 10 \\
\hline I & 0 & 0 & 0,58 & 0,90 & 1,12 & 1,24 & 1,32 & 1,41 & 1,45 & 1,49 \\
\hline
\end{tabular}
yang diambil dapat diterima, yaitu keputusan yang dibuat dapat diandalkan.

\section{DAFTAR PUSTAKA}

[1] F. Stmik et al., "Metode AHP atau Proses Hirarki Analitik merupakan salah satu metode pengambilan keputusan dimana faktor-faktor logika, intuisi, pengalaman, pengetahuan, emosi, dan rasa dicoba untuk dioptimasikan dalam suatu proses yang sistematis. ( Astri Herdiyanti dan ," vol. 13, no. 2, pp. 103-111, 2012.

[2] Intan Trivena Maria Daeng, N. . Mewengkang, and E. R. Kalesaran, "Penggunaan Smartphone Dalam Menunjang 
Aktivitas Perkuliahan Oleh Mahasiswa Fispol Unsrat Manado Oleh," e-journal "Acta Diurna," vol. 6, no. 1, pp. 1-15, 2017.

[3] A. Rahman, "Rahman, Sistem Pendukung Keputusan Pembelian Handphone Menggunakan Metode Analytical Hierarchy Process (AHP) 34," vol. 2, no. April, pp. 34-47, 2013.

[4] E. Ridhawati, . Z., and D. Yunita, "Penerapan Metode Analytical Hierarchy Process (Ahp) Pada Sistem Pendukung Keputusan Pemilihan Laptop," J. Inf. dan Komput., vol. 4, no. 2, pp. 71-77, 2017, doi: 10.35959/jik.v4i2.129.

[5] Sumaryanto, "Upaya Pengambilan Keputusan Yang Tepat," Lkmm Fik Uny, pp. 1-11, 2011.

[6] rizky amelia and H. Afriansyah, "Dasar Pengambilan Keputusan,” pp. 948, 2019, doi: 10.31227/osf.io/a4t5e.

[7] Han, "Bab Ii Landasan Teori," J. Chem. Inf. Model., vol. 53, no. 9, pp. 16891699, 2019.

[8] N. F. Andhini, lucia maria aversa Villela, and L. Bruno, "Konsep AHP (Analytical Hierarchy Process) AHP," J. Chem. Inf. Model., vol. 53, no. 9, pp. 1689-1699, 2017.

[9] A. E. Munthafa, H. Mubarok, J. Teknik, and I. Universitas, "PENERAPAN METODE ANALYTICAL HIERARCHY PROCESS DALAM SISTEM Kata Kunci: Analytical Hierarchy Process, Consistency Index , Mahasiswa Berprestasi . Keywords : Analytical Hierarchy Process,
Consistency Index , Achievement Student b . Kelebihan dan Kelemaha," J. Siliwangi, vol. 3, no. 2, pp. 192-201, 2017.

[10] A. Sasongko, I. F. Astuti, and S. Maharani, "Pemilihan Karyawan Baru Dengan Metode AHP (Analytic Hierarchy Process)," Inform. Mulawarman J. Ilm. Ilmu Komput., vol. 12, no. 2, p. 88, 2017, doi: 10.30872/jim.v12i2.650.

[11] J. Y. Situmorang, Sistem pendukung keputusan pemilihan merek laptop menggunakan metode analytical hierarchy process (ahp). 2017. 